\title{
REVISITING AND RETHINKING CONTEMPORARY URBAN DESIGN
}

\author{
Professor, Doctor Almantas Samalavicius interview with Nikos Salingaros, \\ professor of mathematics at Texas University
}

\begin{abstract}
Urban and architectural theorist Nikos Salingaros, a professor of mathematics at Texas University, San Antonio is affiliated with departments of urbanism in several countries and has made a significant contribution to the understanding of urban planning on a human scale. His important books on various issues in urban and architectural theory are well-known to all members of the profession and academy, especially those seeking for the application of scientific principles in urbanism. Nikos Salingaros has contributed significantly to the New Athens Charter (2003) - an important yet largely neglected document providing timely guidelines for reshaping present mainstream urbanism that still remains under the spell of urban ideology coined by Le Corbusier, Giedion and legions of their followers. A critic of Corbusian doctrines as well as more recent tendencies of urbanism based on stale legacy of Modernism, Nikos Salingaros offers a different approach to the interpretation of contemporary cities and complexity of their functions. He is among those scholars and practitioners who firmly support the principles of urban design promoted by members of the movement known as New Urbanism. Our talk with Nikos Salingaros revolved around the issues of the need to reconsider and reshape our present attitudes prevailing in urbanism.
\end{abstract}

\begin{abstract}
Almantas Samalavičius (A. S.): The urban trends of the second half of the last century were strongly affected by the Athens Charter of 1933 drafted by Le Corbusier and his ideological allies. The New Athens Charter intended to change the course of urbanism to a certain degree; however, the mentality of several generations of urban planners, designers and architects worldwide, and especially in Eastern Europe, remains somewhat under the spell of Corbusian doctrines that are not so easy to abandon. Do you see any shifts in the ideological background of present urban theories and urban practices? Which new theoretical premises would you label as holding the prospect for change in this context?
\end{abstract}

Nikos Salingaros (N. S.): I'm afraid that I see no hope for improvement as long as the present ideological/ pseudo-religious system retains its hegemony of power and controls both city planning and architectural academia. Because Corbusianism is a religious movement, much like other fanatical cults, it will not change just because it is unreasonable. Cults do not listen to reason: they have a blind belief in the infallibility of their own dogmas (ignoring reality that shows their beliefs to be harmful to humanity), and will do anything to hold on to power. We have overwhelming evidence revealing the type of living urban structure that is responsible for a higher quality of life, and it is the opposite of the Corbusian model. Modernists are unmoved by any of this, though I'm not surprised.

Schools continue to teach the same modernist citydestroying typologies to their students. I was fortunate to have contributed to the new 2003 Athens Charter, but I don't see it being applied anywhere, or in replacing that fundamentally evil document, the 1933 Athens Charter. I have never even seen a reference to the new 2003 Athens Charter in architectural academia - it unfortunately seems to have sunk without a trace. You see, Corbusier's pronouncements are Gospel, and several generations of practitioners were made to swear unconditional allegiance to them. So, to answer your question pessimistically, there is no theoretical premise, however persuasive, that can make any difference, because we are not dealing with logic or science, but with dogma, fanaticism, and entrenched power. 
A. S.: New Urbanism has challenged a lot of our previous assumptions about urbanism and the urban future. Thus far, has New Urbanism presented itself as a serious alternative to the former ideology of urbanism? How successful is this challenge so far? Do you think that New Urbanism has established itself to a sufficient degree so as to signify a new approach towards mainstream urban theories and urbanism in general?

N. S.: New Urbanism in its U.S. version, which is what most people think about when alluding to it, is a major though partial success. It arose out of economics and business, as an alternative way to "develop" new Greenfield land using traditional urban codes, mixed use, and more traditional architectural form languages. Less visible in the media, but more important for the long term, is the successful redevelopment of Brownfield sites through New Urbanism. As such, it has been a huge success, producing urban regions that are far better for a human quality of life than suburban sprawl. Nevertheless, it still works within the current political/regulatory system, and that is both its strength and its weakness. The success of New Urbanist projects is overwhelming: the prices rise very quickly, showing user demand in the marketplace. This is success!

I believe that even this economic success is insufficient; however, to break the ideological hold of modernist urbanism that still controls academia, and most importantly, the government planning departments. Both these institutions (academia and planning departments) are staffed by people who will take a long time to retire, but, before they do, they will make sure to hire young persons trained in precisely that inhuman modernist urbanism that has killed our cities. Already I notice that it is "fashionable" to teach architecture students to ridicule new urbanism projects, ignoring their commercial success. That's all you read about in glossy architecture magazines: the "obligatory" attack on New Urbanism by resentful and envious academics.

A. S.: In one of your publications co-written with J. $H$. Kunstler you target high-rise buildings as outdated and compromised; however, big business so far supports clusters of skyscrapers as "necessary" in present-day urbanism and for the urban economy. Your attitude has provoked mixed reactions, and it seems like many professionals, business people and a significant part of society are still hooked on the ideological premises that reigned in the last century. What factors do you think can and will counteract the multiplication of high-rise building in contemporary mega-cities?
N. S.: High-rise buildings destroy cities. Big business loves them because skyscrapers can multiply their investments several times. Now the international construction industry has found its mercenaries among architects who are willing to do what it bids, and who eagerly and dishonestly promote "sustainable" and "green" skyscrapers. Those are ridiculous. They are phenomenally expensive to build and maintain, and even if everything goes well, their material lifetime is astonishingly short. This is an unaffordable fashion product that has a short built-in lifetime because of the high-tech materials and systems necessary to maintain it. But I still don't see any forces that can counteract the immense financial and political power of multinational construction and engineering companies that want to build skyscrapers around the world. I hate to say this, but only an economic (not merely environmental) collapse will give rise to a drastic revision of building codes so as to discourage the building of skyscrapers. We are seeing the beginnings of this in Asian cities where the air has become unbreathable because of pollution from coal-burning power plants. Why were these built? Well, to be able to supply electrical energy and services to clusters of skyscrapers! But this unprecedented pollution is still not enough to change the mindset of building skyscrapers. It will have to get far, far worse to get the government's attention.

A. S.: Some of the new trends that are visible in the field of urbanism and urban studies seem to have parallels with a movement that is broadly labeled as New Economics. The spokesmen for New Economics challenge economic globalization on theological, philosophical and simply rational grounds. What are the prospects of arriving at a new kind of consensus about urbanism? Or will the mainstream attitudes continue to guide the course of urbanism for decades to come?

N. S.: I am not qualified to comment on any future economic movement. What I can say is that there is a growing peer-to-peer movement in urbanism (in which I'm involved) and also naturally in governance, politics, and social cooperation. Mainstream attitudes will most certainly continue to guide the course of urbanism until we reach - and even get well into a massive collapse. Even then, it's not clear whether a peer-to-peer alternative could replace the current centralized system. What history teaches is not encouraging: in situations of crisis, another power simply takes over the old system and very soon becomes centralized itself. Since the present system is focused on feeding and perpetuating itself, it's very easy for any 
replacement system to simply continue the old system's practices. The "smoothest" revolution occurs when the same people remain in power by adopting superficial changes and using the existing propaganda machine to convince people otherwise.

Thus, the only realistic possibility for real change I see is a co-existence between the present power system, and a peer-to-peer system that remains on the outside, but which gradually involves more and more people. This alternative approach can be applied where the central power simply has no reach: for example, in locations which are of no economic interest to the central power; or in parts of the world where the central power is not so powerful that it can interfere and forbid the construction of human-scale cities. This could be within states that still give away their prime real estate to multinationals, but who simply cannot be bothered by outlying regions. The creation of a parallel society is certainly not a new phenomenon. Whenever the central government fails to serve its people, alternative systems of mutual help and survival emerge, even in a totalitarian state.

A. S.: As a scientist and mathematician you provided a rational critique of urban and architectural theories that have adherents worldwide, and you presented an alternative theoretical paradigm rooted in urban "networking". And yet what do you see as the gross fallacies in the assumptions of the most influential theories of the twentieth century? How can the former myths be dismantled? Moreover, as we well know, professional mythologies resist revisions and fight for their own survival for many reasons, not least psychological ones. Do you envision any changes in university programs of urban studies, urbanism and architecture?

N. S.: I'm sorry to say that I don't see any hope for changes in the positive sense. I do observe radical movements in university programs, but those are driven by the most fashionable practitioners grasping to get commissions to build. Those "star" architects are after more work, generating promotion and public relations, and not really concerned in building a human-scale city. So we do see an adaptive reaction of the system to external threats (coming from me and my friends!), and it adapts brilliantly by taking some of our ideas and misapplying them. Therefore, the vocabulary and images of what we propose as a human-scale city are misappropriated by those who in practice do exactly the opposite.

Academia unthinkingly parrots what the most fashionable practitioners happen to be doing, regardless of the actual value of their projects. Instead of analyzing the built environment, as one might expect from its position in a university, architectural academia instead acts as a fan club for the "stars". The media plays along in a thoroughly corrupt manner, presenting the second-hand misapplication of our original ideas in a really terrible context, but praising those architects for their "innovation". We are of course ignored and marginalized, since we represent the genuine innovation. That's not welcome: only artificial innovation that comes from within the hegemonic system is allowed. Again, the purpose of "revisions" in university programs is to keep the same players in power, so as to maintain the ideology those professors learned when they themselves were students, and not to embrace actual change for the better. The myths upon which Modernism is based are quite ridiculous, but they can never be dismantled since they represent religious dogma. And the new myths that are slowly replacing them are not better: their only purpose is to perpetuate the disconnection of design from human biology initiated by the modernists.

A. S.: In earlier periods and some time in the last century urban prospects were mentally shaped by architects. One can recall ideas of the Grand Designer, Universal Architect, etc. put forward by leading architects and urban designers. These days, however, architects are just a part of bigger structures of development agencies, multidisciplinary firms and other institutions where architects are far less powerful and are influenced by demands of development, financial donors (or just big business). How can their pressure then be counteracted? How far can local communities and governments resist these pressures as well as having their say in such matters as urban prospects?

N. S.: Architects are not, and have never been, the movers behind large-scale projects. It is political and economic powers that provide the force and financing, and that convince the legal authorities to approve a project. The architect is the visible "tail" but not the "dog" whose body is hidden from publicity. Of course, it is now convenient to put the architects in the limelight, but this is part of the marketing scheme and does not represent reality. A construction company and developer decide on some giant project, then choose an architect with media recognition to "sell" this project to the public. A hand-picked jury, composed of architectural insiders, will of course pick one of the reigning "star" architects (it doesn't matter which one - the result will be much the same). Much 
more important than the architect is the engineering company involved in a project, which incidentally, makes several times the profits from a project than the architect does. Notice how the biased press always talks about the "star architect" of a major project, but never about the engineering firm (which tends to be one of three global firms connected to multinationals), nor about the other key players. Local communities can do absolutely nothing about this. Local government, which ideally should be responsible and protect the community, usually gives in to massive pressure from those with money who wish to build something of their choice. Money talks louder than democracy.

\section{A. S.: During recent decades there were ideas and a movement towards car-free cities worldwide, moreo- ver because problems of energy are becoming no less visible than they were, say, during the energy crisis of 1973. Can environmental considerations and growing ecological awareness make an impact upon urban plan- ning and urban design? And what are the prospects of building smaller and more rational cities? Some authors still cherish the legacy of the Garden-city movement that had its supporters in the Western hemisphere and per- haps in other parts of the world. Do you have any faith in this legacy? Or to put it in another way - what are the prospects of a sustainable city model?}

N. S.: Firstly, total pedestrianization kills the city. A living city consists of overlapping transport networks that complement and feed each other. Even "pedestrian" Venice is fed by its canal network. But the failed practice of "urban design through images" goes ever on, sponsored by well-meaning governments and organizations the world over. The same people who gave us the totalitarian modernist city of highways cutting through city centers now propose digging up downtown streets and replacing them with parks, open pools, and hard pedestrian plazas. All of these are nicely ordered on formal plans that ignore flows, connections, and the time-distribution of users. If those pretty images are ever implemented, they will mark the death of the city center by isolating it from the rest of the transportation network. Urban plazas work in a mixed though highly residential environment, but largely commercial downtowns cannot "feed" urban open spaces so as to keep them alive. This is a primary rule ignored by such projects, but it is understandable, coming as it goes from the modernist legacy of design through images, not human behavior and history.
Secondly, the Garden City movement was not altogether a good thing, because the models proposed then (more than one century ago) were formal in plan (a very bad precedent), and were entirely dependent upon a massive transportation system. In short, the Garden City was not a compact city model of mixed use that saves transportation energy. Present-day suburbia inherits many of its worst deficiencies from the Garden City. There are indeed prospects for a sustainable city, but those come from an entirely distinct approach to urban structure. The complexity of living, sustainable urban fabric is altogether different from that seen in the Garden Cities, which tend to be very simplistic even though their good point is to contain necessary green areas. There is where the fundamental difference lies - in the living city's high degree of geometrical and network complexity. As far as building smaller cities, as long as we have cheap petrol available, nobody is going to do that, period. It will take a global oil collapse before people are forced into compact cities. They are not going to do it voluntarily. 